\title{
Russisk forsvarspolitikk og militær tilstedeværelse i Kaukasus og Sentral Asia
}

\author{
Security in the Caucasus. Russian policy and military posture \\ Jakob Hedenskog, Erika Holmquist \& Johan Norberg \\ Stockholm: Totalförsvarets forskningsinstitut 2018 \\ Rapportnr. FOI-R-4567-SE \\ 98 sider. ISSN 1650-1942
}

\author{
Security in Central Asia. Russian policy and military posture \\ Jakob Hedenskog, Erika Holmquist \& Johan Norberg \\ Stockholm: Totalförsvarets forskningsinstitut 2019 \\ Rapportnr. FOI-R-4756-SE \\ 94 sider. ISSN 1650-1942
}

Anmeldt av Kristin Fjastad [ph.d., seniorforsker ved Norsk utenrikspolitisk institutt, kfj@nupi.no]

De siste årene har Russlands vilje til å bruke militærmakt, blant annet i Ukraina og Midtøsten, ført til fornyet interesse for det russiske forsvaret. Mye av denne interessen har dog satt søkelys på Russlands globale ambisjoner eller forholdet til Vesten. Samtidig har Russlands annektering av Krim og konflikten i Ukraina siden 2014 skapt usikkerhet, til og med frykt, i andre naboland med en stor russisk minoritet, som Kasakhstan. Totalförsvarets forskningsinstitutt (FOI) har publisert to rapporter som ser på nettopp sikkerhetssituasjonen i to regioner som av flere blir sett på som Russlands bakgård, Kaukasus og Sentral-Asia. Rapportene beskriver Russlands militære innretning og struktur - forstått som personell og materiell som påvirker kapasiteten til krigføring - og tilnærming til militære konflikter i de to regionene. Med situasjonen etter 2014 som bakteppe stiller rapportene parallelle overordnede forskningsspørsmål: Hva er Russlands muligheter for å bruke militær intervensjon til å løse mulige kriser i disse regionene?

FOI har gjort en viktig jobb med å kartlegge og presentere de russiske militærstrukturene som finnes og er tilgjengelige for militære operasjoner i de to regionene. Utover denne kartleggingen forsøker de også å plassere den militære strukturen 
inn $\mathrm{i}$ et større sikkerhetspolitisk bilde giennom analyse av russiske forsvars- og utenrikspolitiske offisielle dokumenter, samt feltarbeid i Moskva, Baku, Jerevan, Tbilisi, Nur-Sultan (Astana), Dusjanbe og Bisjkek i 2017 og 2018. Rapportene føyer seg inn i rekken av grundige publikasjoner fra FOI om russisk sikkerhetspolitikk og forholdet til de andre statene i det tidligere Sovjetunionen.

Begge rapportene starter med en mer generell diskusjon av russisk militær strategi og tilnærming til ulike typer konflikt. Deretter drøfter rapportene Russlands relasjoner med, og politikk overfor, de ulike landene og (potensielle) konfliktene i regionene. Analysen av Russlands militære struktur i de to regionene viser at den i Sør-Kaukasus er mer tilpasset en regional krig, mens den i Sentral-Asia først og fremst er satt opp for krisehåndtering. Dette forklares først og fremst med de såkalte frosne konfliktene i Nagorno-Karabakh, Sør-Ossetia og Abkhasia, hvor Russland er mer direkte involvert.

FOI beskriver Russlands hovedinteresse i begge regionene som primært å forhindre «fargerevolusjoner» samt å beholde disse landene innen sin interessesfære, med andre ord å begrense relasjonene med andre aktører, først og fremst NATO, men også EU. I Sentral-Asia-rapporten er det et eget kapittel som diskuterer eksterne aktører og de regionale statenes respons, mens slike diskusjoner $\mathrm{i}$ Kaukasus-rapporten er del av kapittel 5 «Russisk press: konsekvenser for sikkerheten i Sør-Kaukasus».

Til tross for flere likhetstrekk, er det også vesentlige forskjeller mellom de to regionene og landene som er omtalt i rapportene. Begge rapportene spenner vidt, og beslutningen om å dekke hele regioner som omfatter stater med svært forskjellige relasjoner med Russland kunne gjerne vært noe bedre begrunnet. Dette blir spesielt tydelig i Kaukasus-rapporten, som favner både Nord- og Sør-Kaukasus. Forbindelsen mellom Russlands militære innretning og struktur nord og sør for Kaukasusfjellene kunne ha vært diskutert i større detalj i rapporten. Videre gaper rapporten over mye ved å dekke Russlands forhold til de tre statene i Sør-Kaukasus, samt Iran og Tyrkias roller og innflytelse i regionen. Russlands nærvær er preget av konfliktene i Nagorno-Karabakh, Sør-Ossetia og Abkhasia. Georgiske myndigheter beskriver etter krigen i 2008 Russland som «landets største trussel». I Armenia har Russland derimot sin eneste militærbase i regionen, og russiske soldater vokter Armenias grense mot Tyrkia.

På grunn av de geografiske utfordringene knyttet til å flytte styrker og materiell fra nord til sør gjennom Kaukasus-fjellene, har Russland plassert militært utstyr ved basene i Armenia og Georgia og sikret kontroll over viktige transportruter. Dette gir mulighet til å doble styrketallet ved kun å flytte personell. Forfatterne beskriver Russlands militære innretning i Sør-Kaukasus som «overdimensjonert gitt den nåværende konfliktsituasjonen» (s. 69). Forklaringen på dette er på det strategiske nivået: styrkedisponering gir mulighet til å dominere regionen og hindre ekstern innflytelse. Av de regionale stormaktene er det bare Russland som er beredt til å gå inn militært. Russland, Iran og Tyrkia er partnere i Syria og deler interesse i å holde 
Kaukasus «stabilt ustabilt», siden oppmerksomheten nå først og fremst er rettet mot Midtøsten. Ifølge forfatterne er Russland militært satt opp for en storskala-konflikt i det sørlige krigsteateret, inkludert Midtøsten. Samtidig peker forfatterne på at dette ikke er det mest sannsynlige scenarioet. Av de fire mulige konflikt-scenarioene som trekkes frem i rapporten, er det en oppblussing av konflikten i Tsjetsjenia som anses som mest sannsynlig.

Hva gielder Sentral-Asia, er relasjonene mellom Russland og de regionale statene av en annen karakter, og det er også andre eksterne aktører involvert. En viktig forskjell mellom de to regionene er at kjernevåpeninstallasjoner er en viktig del av Russlands militære struktur i Sentral-Asia. En annen viktig forskjell er at tre av de sentralasiatiske statene deler grense med Afghanistan. Kapittel 3 diskuterer hvilke aktører som potensielt kan skape konflikt i Sentral-Asia, og peker blant annet på konflikten i Afghanistan som en som har forgreininger til Sentral-Asia. Dette har vært tema for flere tidligere rapporter fra FOI. Dette er et argument som gientas ofte, men det er lite empirisk belegg for påstanden om at konflikten i Afghanistan kan «spre seg» til Sentral-Asia.

Kapittel 4 belyser Kinas økende tilstedeværelse i regionen, først og fremst økonomisk, men også sikkerhetsmessig. Potensielle reaksjoner og den militære kapasiteten til de sentralasiatiske statene blir også diskutert. Rapporten peker på endringene i Usbekistan etter president Islam Karimovs død i 2016, og hevder at risikoen for militære konflikter mellom landene i regionen nå er redusert. Spesielt gjelder dette relasjonen mellom Tadsjikistan og Usbekistan, som lenge har vært betent. Mulighetene for sterkere regionalt samarbeid kan ifølge forfatterne vanskeliggjøre Russlands forsøk på en splitt og hersk-strategi. Rapporten diskuterer også Russlands direkte engasjement i to konflikter i Sentral-Asia etter Sovjetunionens fall: borgerkrigen i Tadsjikistan fra 1992-1997 og hendelsene i Kirgisistan i 2010. Her er det viktig å nevne at Russland mottok gjentatte forespørsler om støtte fra kirgisiske myndigheter, men endte med å ikke engasjere seg militært for å håndtere krisen i Kirgisistan i 2010.

Rapportene gir et solid overblikk over situasjonene i de to regionene, men bærer noe preg av at problemstillingene innenfor hver region spenner bredt. Som nevnt ovenfor, er spørsmålet hva man tjener og taper ved å dekke så varierte problemstillinger i samme rapport. Dette er spesielt tydelig i Kaukasus-rapporten, hvor FOI ikke bare kombinerer Nord- og Sør-Kaukasus, men hvor også Russlands relasjoner med de tre landene i Sør-Kaukasus er så forskjellige. Det er vel verdt å se situasjoner og utviklingstrekk i sammenheng, men forsøket på å dekke både Russlands militære struktur, politikk og relasjoner til de forskjellige land i regionene, samt andre aktører, kan gå på bekostning av mer detaljerte og oppdaterte analyser. Rapportene kunne gjerne brukt noe mindre plass på historie og bakgrunn, og det er vanskelig å få et klart inntrykk av hva og hvordan noe har endret seg etter 2014. Ett eksempel på dette er diskusjonen av styrkesammensetningen i Kaukasus opp mot sikkerhetssituasjonen i Midtøsten. Her ville det vært interessant å vite hva som «kom først». 
Samtidig er det prisverdig at FOI, i en tid der mange er opptatt av Russlands aktiviteter i Ukraina og Midtøsten, bruker ressurser på å oppdatere kunnskapen om hva som foregår andre steder.

Rapportene konkluderer med at «Russlands strategier for å beskytte sine interesser ser ut til å virke" (2018, s. 58). Noe av årsaken til dette, hevder forfatterne, er manglende interesse fra andre aktører - blant annet er USA og EU ikke så involvert som de kunne ha vært. De uløste konfliktene i Sør-Kaukasus gagner Russland, og vil derfor, mest sannsynlig, forbli uløst i de neste årene også. 